\title{
Nutrient loss and water quality under extensive grazing in the upper Burdekin river catchment, North Queensland
}

\author{
P.J. O'Reagain ${ }^{\mathrm{a}, *}$, J. Brodie $^{\mathrm{b}}{ }^{\text {, G. Fraser }}{ }^{\mathrm{c}}$, J.J. Bushell ${ }^{\mathrm{a}}$, C.H. Holloway ${ }^{\mathrm{a}}$, \\ J.W. Faithful ${ }^{\mathrm{b}}$, D. Haynes ${ }^{\mathrm{d}}$ \\ a Department of Primary Industries and Fisheries, P.O. Box 976, Charters Towers, Queensland 4820, Australia \\ b Australian Centre for Tropical Freshwater Research, James Cook University, Townsville 4811, Australia \\ ${ }^{c}$ Department of Natural Resource and Mines, 80 Meiers Rd., Indooroopilly, Queensland 4068, Australia \\ ${ }^{\mathrm{d}}$ Great Barrier Reef Marine Park Authority, P.O. Box 1379, Townsville, Queensland 4810, Australia
}

\begin{abstract}
Increased sediment and nutrient losses resulting from unsustainable grazing management in the Burdekin River catchment are major threats to water quality in the Great Barrier Reef Lagoon. To test the effects of grazing management on soil and nutrient loss, five 1 ha mini-catchments were established in 1999 under different grazing strategies on a sedimentary landscape near Charters Towers. Reference samples were also collected from watercourses in the Burdekin catchment during major flow events.

Soil and nutrient loss were relatively low across all grazing strategies due to a combination of good cover, low slope and low rainfall intensities. Total soil loss varied from 3 to $20 \mathrm{kgha}^{-1}$ per event while losses of $\mathrm{N}$ and $\mathrm{P}$ ranged from 10 to $1900 \mathrm{gha}$ and from 1 to $71 \mathrm{gha}^{-1}$ per event respectively. Water quality of runoff was considered moderate across all strategies with relatively low levels of total suspended sediment (range: $8-1409 \mathrm{mgl}^{-1}$ ), total $\mathrm{N}$ (range: $101-4000 \mu \mathrm{gl} \mathrm{l}^{-1}$ ) and total $\mathrm{P}\left(\right.$ range: $14-609 \mu \mathrm{gl} 1^{-1}$ ). However, treatment differences are likely to emerge with time as the impacts of the different grazing strategies on land condition become more apparent.

Samples collected opportunistically from rivers and creeks during flow events displayed significantly higher levels of total suspended sediment (range: $10-6010 \mathrm{mgl}^{-1}$ ), total $\mathrm{N}$ (range: $650-6350 \mu \mathrm{gl}^{-1}$ ) and total $\mathrm{P}$ (range: $50-1500 \mu \mathrm{gl} 1^{-1}$ ) than those collected at the grazing trial. These differences can largely be attributed to variation in slope, geology and cover between the grazing trial and different catchments. In particular, watercourses draining hillier, grano-diorite landscapes with low cover had markedly higher sediment and nutrient loads compared to those draining flatter, sedimentary landscapes.

These preliminary data suggest that on relatively flat, sedimentary landscapes, extensive cattle grazing is compatible with achieving water quality targets, provided high levels of ground cover are maintained. In contrast, sediment and nutrient loss under grazing on more erodable land types is cause for serious concern. Long-term empirical research and monitoring will be essential to quantify the impacts of changed land management on water quality in the spatially and temporally variable Burdekin River catchment. Crown Copyright (c) 2004 Published by Elsevier Ltd. All rights reserved.
\end{abstract}

Keywords: Extensive grazing; Nitrogen; Phosphorus; Sediment loss; Water quality

\section{Introduction}

Increased sediment and nutrient inputs from terrestrial runoff have been identified as major threats to the

\footnotetext{
${ }^{*}$ Corresponding author. Fax: +61 747874998.

E-mail address: peter.oreagain@dpi.qld.gov.au (P.J. O'Reagain).
}

Great Barrier Reef (GBR) lagoon (Brodie, 2002; Furnas, 2003; Fabricius and De'ath, 2004). The Burdekin River is the single largest source of these inputs into the lagoon, delivering on average 3.77 million tonnes of fine sediment as well as 8633 tonnes of $\mathrm{N}$ and 1338 tonnes of P per annum (Furnas, 2003). This is estimated through modelling to be approximately six times the 
natural suspended sediment export, four times the natural total $\mathrm{N}$ export and six times the natural total $\mathrm{P}$ export (Brodie et al., 2003). Given that $92 \%$ of the 133 $510 \mathrm{~km}^{2}$ Burdekin catchment is under pastoral use, the vast majority of these sediments and nutrients are believed to originate from the extensive grazing lands of the interior (Roth et al., 2003). The amount of sediments and nutrients emanating from these grazing lands is obviously largely dependent upon land management. Grazing in particular, is likely to have a major impact upon soil loss and runoff, through its effects upon plant cover and soil surface condition. Surveys in the upper Burdekin (De Corte et al., 1991) indicate that large areas of the catchment are in poor to moderate condition. This suggests that current rates of nutrient and sediment export to the GBR lagoon will be maintained or may even increase in the future.

In major flows, water from the Burdekin River disperses in flood plumes which may reach as far north as Cairns (Wolanski and van Senden, 1983) and, at times, to the outer edge of the GBR (Devlin et al., 2001; King et al., 2001). The reefs on the inner shelf of the GBR between the mouth of the Burdekin River and Cairns are known to be at highest risk from the impacts of terrestrial runoff (Devlin et al., 2003) and discharge from the Burdekin River is regarded as being a major component of this risk (McCulloch et al., 2003). Reefs in this section of the GBR have been degraded through a combination of acute mortality events (bleaching, crown of thorns starfish, cyclones) and chronic poor water quality conditions which prevent reef recovery (Fabricius and De'ath, 2004).

Despite the importance of grazing management in determining water quality, there is a relative paucity of studies relating soil loss to ground cover in the semi-arid tropical savannas. Studies conducted on grano-diorite and sedimentary landscapes (McIvor et al., 1995; Scanlan et al., 1996) showed that runoff and sediment loss increased sharply as cover declined, with some sites losing up to $1000 \mathrm{~kg} \mathrm{ha}^{-1}$ of sediment per annum under grazing (Scanlan et al., 1996). Unfortunately, neither study quantified the relationship between cover and nutrient loss from these systems. These studies were also conducted on relatively small plots: under these conditions much of the sediment moved is likely to be redeposited before entering water ways, making it difficult to extrapolate sediment losses to larger catchment scales. Roth et al. (2003) recently measured runoff and water quality at a range of spatial scales in the savannas but this work was again conducted on the grano-diorite landscapes near Charters Towers.

Major knowledge gaps are thus evident concerning the relationship between land management and runoff in the semi-arid landscapes of the Burdekin. These are firstly, how runoff is related to grazing management on other land types, particularly the relatively flat, infertile, tertiary sediments, which make up $\approx 20 \%$ of the Burdekin catchment. Secondly, how grazing management affects water quality, particularly $\mathrm{N}$ and $\mathrm{P}$ concentrations, and thirdly, the extent to which results from relatively small scale studies can be scaled up to the catchment or sub-catchment level. These issues require urgent resolution if science is to competently inform government and regional catchment bodies attempting to implement policies such as the Reef Water Quality Protection Plan and the National Action Plan for Salinity and Water Quality.

In this paper we present preliminary data from a long-term study aimed at quantifying the effects of different grazing management strategies on soil and nutrient loss on a landscape derived from tertiary sediments. To put the results of the study in context, we also present water quality data collected from a number of creeks and rivers draining a range of land types in the Burdekin catchment. We emphasise the preliminary nature of our data and urge the need for continued long-term research to develop robust relations between management and water quality in the Burdekin catchment.

\section{Methods}

\subsection{Grazing trial}

The study was conducted on Wambiana station near Charters Towers, Australia (Fig. 1). Mean annual rainfall is $650 \mathrm{~mm}(\mathrm{CV}=40 \%)$. The area is drained by the Cape and Campaspe rivers, which are important tributaries of the Burdekin River. Ten $\approx 100$ ha paddocks were established in 1997 (O'Reagain and Bushell, 1999), with paddocks containing similar areas of yellow kandosol, brown sodosol and black vertosol soils (Isbell, 1996). Five grazing strategies, replicated twice, were tested in the trial. These were (i) light stocking, (8 ha per large stock unit (LSU): defined here as a $450 \mathrm{~kg}$ steer), (ii) heavy stocking (4ha $\mathrm{LSU}^{-1}$ ), (iii) variable stocking - stock numbers adjusted annually at the end of the wet season according to available herbage (range: 3-10 ha LSU ${ }^{-1}$ ), (iv) a variable-SOI (Southern Oscillation Index) strategy-stock numbers adjusted annually in November according to available herbage and SOIbased rainfall predictions (range: $3-10 \mathrm{ha} \mathrm{LSU}^{-1}$ ) and (v) rotational spelling $\left(6 \mathrm{haSU}^{-1}\right)$ - one third of the pasture spelled annually during the wet season in order to buffer inter-annual variability in feed supply. Paddocks were stocked with between 10 and 35 Brahman$\mathrm{X}$ steers of $\approx 2.5$ years of age.

Bounded runoff catchments $(\approx 1$ ha) were established in undisturbed woodland in a single paddock of all treatments in either October 1998 (heavy, SOI, and rotational spell) or November 1999 (light and variable). All catchments are located in a Eucalyptus brownii commu- 


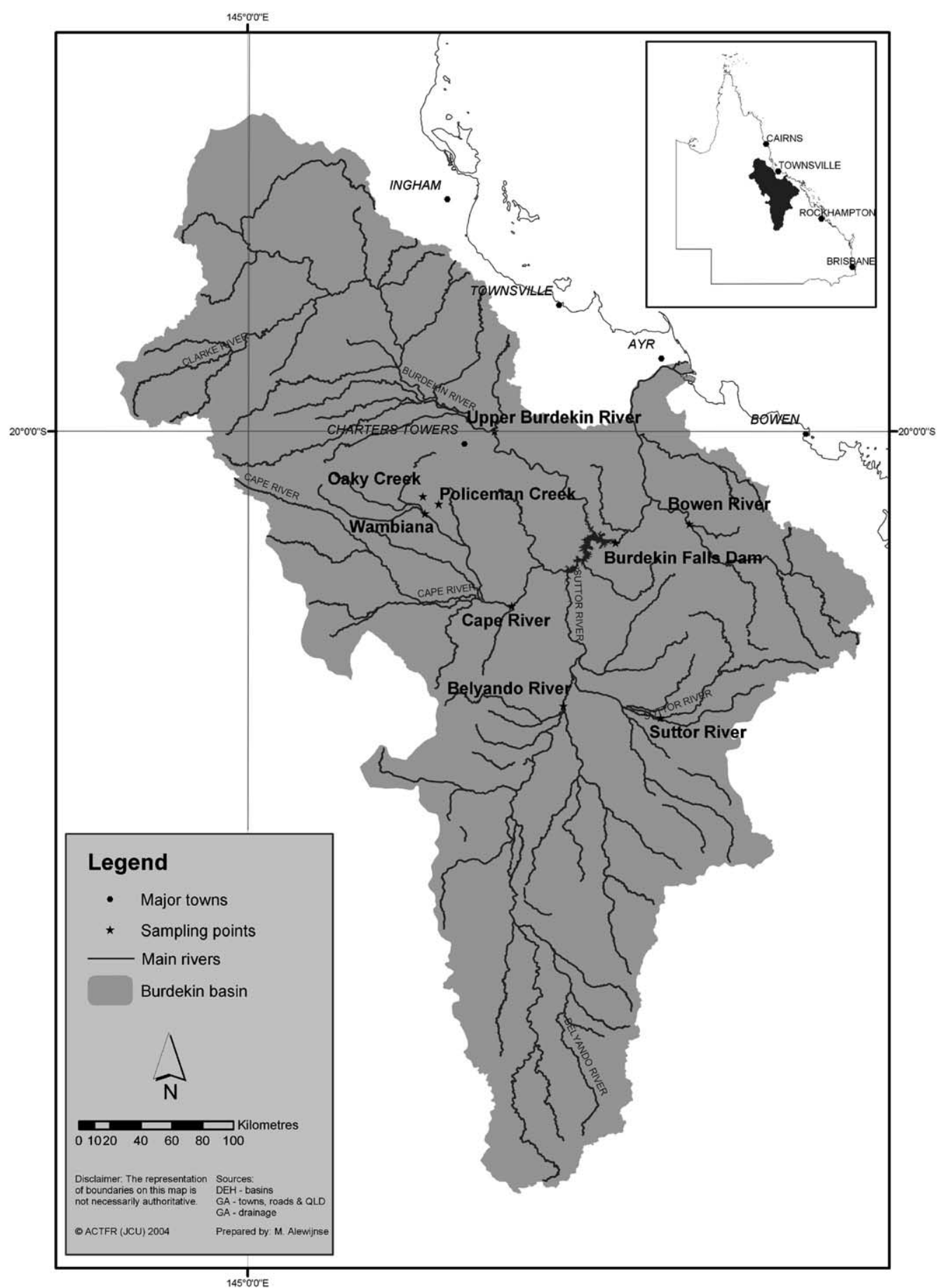

Fig. 1. A map of the Burdekin River catchment area showing the location of the Wambiana study area, and the event sampling points on the major creeks and rivers (Source: Queensland Department of Natural Resources, Mines and Energy, 2003).

nity overlying a Chrysopogon fallax-Bothriochloa ewartiana herbaceous layer on gently sloping (0.5$1.5 \%$ ) brown-grey sodosol (Isbell, 1996) soils. These relatively infertile, hard setting, poorly drained and only slowly permeable soils are widely distributed throughout northern Australia. Projected ground cover was estimated subjectively to the nearest 5\% every 3-4 months using a $0.25 \mathrm{~m}^{2}$ quadrat (100 placements) along fixed transects located on each runoff site (Tothill et al., 1992). Cover was usually recorded in the mid-wet, early dry and late dry seasons.

Runoff was collected at the bottom of catchments by wing walls which funnel runoff towards a sediment trap $(1 \times 1 \times 0.2 \mathrm{~m})$ and San-Dimas flume $(2.5 \times 0.5 \times 0.5 \mathrm{~m})$. Flow height and duration through the flume were recorded at one-minute intervals using Macquarie 
borehole loggers (Windstream technologies, Mona Vale, NSW, Australia), allowing quantification of runoff rates and volumes. Rainfall quantities and intensities were recorded at one-minute intervals using tipping-bucket pluviometers.

Water samples were automatically collected from flumes using Macquarie (1999-2001) or refrigerated ISCO 3700 (2002 onwards) auto-samplers (ISCO, Lincoln, Nebraska, USA). To minimise expense, samplers were initially only fitted to the 'heavy' and 'variable' treatments but in November 2002 ISCO samplers were installed at all sites. Samplers were programmed to extract $500 \mathrm{~mL}$ samples with the first flush of water through the flume and thereafter at every $10 \mathrm{~mm}$ change in flow height. Depending upon site accessibility (a function of localised flooding), water samples were generally collected within $24 \mathrm{~h}$ of a runoff event. Samples were returned to Charters Towers on ice where they were subsampled for nutrients analyses, which included filtration using pre-rinsed Sartorius Minisart filter modules $(0.45 \mu \mathrm{m}$ pore size). All samples were stored on ice prior to their transfer to the Water Quality Laboratory, Australian Centre for Tropical Freshwater Research (ACTFR), James Cook University, Townsville.

\subsection{Sampling of rivers and creeks}

During moderate to major flood events reference samples were collected opportunistically from a number of creeks and rivers in the region surrounding the grazing trial, i.e. Policeman Creek, Oaky Creek, the Campaspe River and the Burdekin River at Macrossan (Fig. 1). The watercourses sampled varied markedly in catchment size, topography, geology, land type and, in some cases, stocking pressure. In addition, as part of a community based water quality monitoring program (Brodie et al., 2004), samples were collected during flow events from the end of major sub-catchments of the Burdekin (Bowen, Suttor, Belyando, and Cape Rivers) (Fig. 1). These sub-catchments (including the upper Burdekin above Macrossan) also vary greatly in topography, geology, soil types and hydrology. However, the whole study area falls within the Burdekin Dry Tropics Region, where land use is dominated by extensive rangeland cattle grazing. Land use is thus relatively uniform although land management practices (stocking pressure, spelling, fire etc) and hence pasture cover, may vary considerably. In general, an attempt was made to collect at least five samples at each site representing the pre-event baseflow condition, the rising stage of the hydrograph, the peak of the hydrograph and early and late stages of the falling limb of the hydrograph. In some cases, many more samples were collected during the flow event while in a few cases less than the desired five samples were collected. Sample numbers at each site are shown in Fig. 4.
Samples were filtered and frozen on site where appropriate and later transported to the laboratory for analysis. Samples were collected at the major sub-catchment sites in the moderate flow events of January-March 2003 and the small flow events of February 2004. Samples from the Burdekin Dam were collected as part of an Australian Centre for Tropical Freshwater Research (ACTFR) study conducted between 1987 and 1996 (Griffiths and Faithful, 1996; Faithful and Griffiths, 2000; Faithful, unpublished data). Total suspended sediment results were depth averaged for samples collected in the Burdekin and Suttor River arms of the reservoir and at the dam wall during periods of flow that exceeded $2000 \mathrm{MLd}^{-1}$ (flow data were derived from Queensland Department of Natural Resources and Mines monitoring and take into account that the majority of dam releases for downstream requirements were generally at or below $1900 \mathrm{MLd}^{-1}$ ).

\subsection{Sample analysis}

Water samples were analysed at ACTFR for total suspended sediment (TSS), total nitrogen (TN) and phosphorus (TP), total filterable nitrogen (TFN) and total filterable phosphorus (TFP), ammonia, $\mathrm{NO}_{X}$ (nitrate + nitrite) and filterable reactive phosphorus (FRP). Samples for TSS analyses were filtered through pre-weighed Whatman GF/C filter membranes and oven dried at $103-105^{\circ} \mathrm{C}$ for $24 \mathrm{~h}$ and re-weighed to determine the dry TSS weight as described in APHA (1998). Samples for TN and TP, and TFN and TFP were digested in an autoclave using an alkaline persulfate technique (modified from Hosomi and Sudo, 1987) and the resulting solution simultaneously analysed for $\mathrm{NO}_{X}$ and FRP by segmented flow autoanalysis using an ALPKEM Flow Solution II (Alpkem Corporation, Wilsonville, Oregon, USA). The analyses for $\mathrm{NO}_{X}$, ammonia and FRP were also conducted using standard segmented flow auto-analysis techniques following standard methods (APHA, 1998). Particulate nutrient concentrations were estimated by the subtraction of the total filterable nutrient concentration from the total nutrient concentration. Similarly, filterable organic nitrogen or phosphorus (FON or FOP) were estimated by the subtraction of $\mathrm{NO}_{X}$ plus ammonia (for nitrogen) or FRP (for phosphorus) from the total filterable nitrogen or phosphorus (TFN or TFP) concentration.

\section{Results and discussion}

\subsection{Grazing trial}

Annual rainfall (July-June) exceeded the long-term average for the area over the first three years of the study but was markedly below average in subsequent 


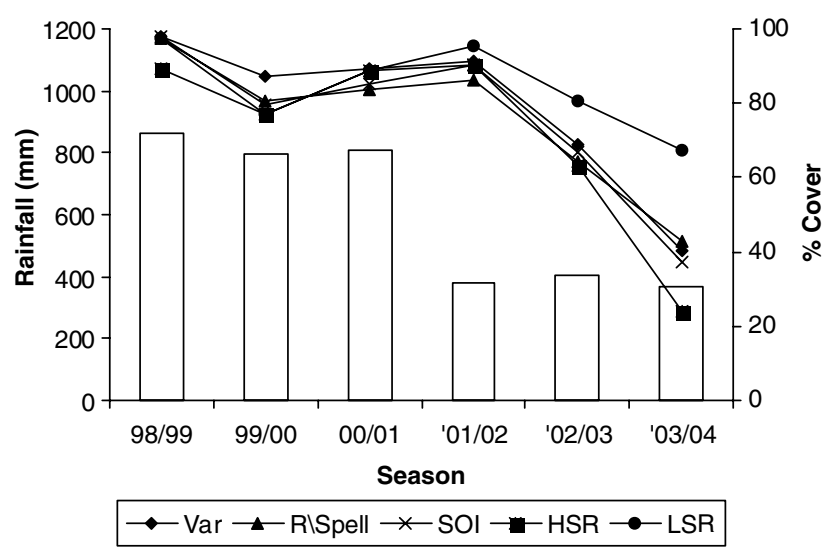

Fig. 2. Total annual rainfall (July-June) for the study period as well as projected ground cover for the five grazing treatments at the Wambiana study site. Annual ground cover values are means derived from late dry and late wet season surveys (Var = variable, R/ Spell $=$ rotational spell,$\quad$ SOI $=$ Southern oscillation index, $H S R=$ heavy stocking rate and $\mathrm{LSR}=$ light stocking rate).

seasons (Fig. 2). Similarly, projected ground cover was very high across all treatments until mid-2002 but declined progressively thereafter due to the combined effects of grazing and below average rainfall. As expected, the magnitude of this decline was strongly dependent upon grazing pressure: between 2001 and 2004 cover declined by 66 percentage points under heavy stocking compared to a decline of only 27 percentage points under light stocking (Fig. 2).

Ten to twelve runoff events occurred per site over the five-year experimental period, but this number varied between treatments due to spatial variation in rainfall distribution across the trial site. This low number of events may be partly attributed to the nature of the rainfall over the study period: although rain was recorded on 257 occasions, only 23 events exceeded $40 \mathrm{~mm}$ and only about half of these were of sufficient size and/or intensity to generate a runoff event. Only six runoff events exceeding $5 \mathrm{~mm}$ were recorded over the experimental period, which reflects the relatively low propensity for surface runoff in these low slope, sedimentary landscapes, even during above average rainfall years. A summary of the major runoff events recorded in the variable-SOI strategy is presented in Table 1: major runoff events also occurred in the other four treatments on these dates but for purposes of brevity these data are not shown.

There were no clear or consistent differences between treatments in terms of percentage runoff (data not shown), sediment loss or water quality (Fig. $4 \mathrm{a}-\mathrm{j}$ ). The lack of a treatment effect is probably not surprising considering the high ground cover levels measured across all treatments through the first five years of the trial. These cover levels in turn reflect the good seasons and the relatively short period over which the grazing treatments had to express themselves. In time, the prolonged effects of heavy grazing pressure upon cover, soil surface

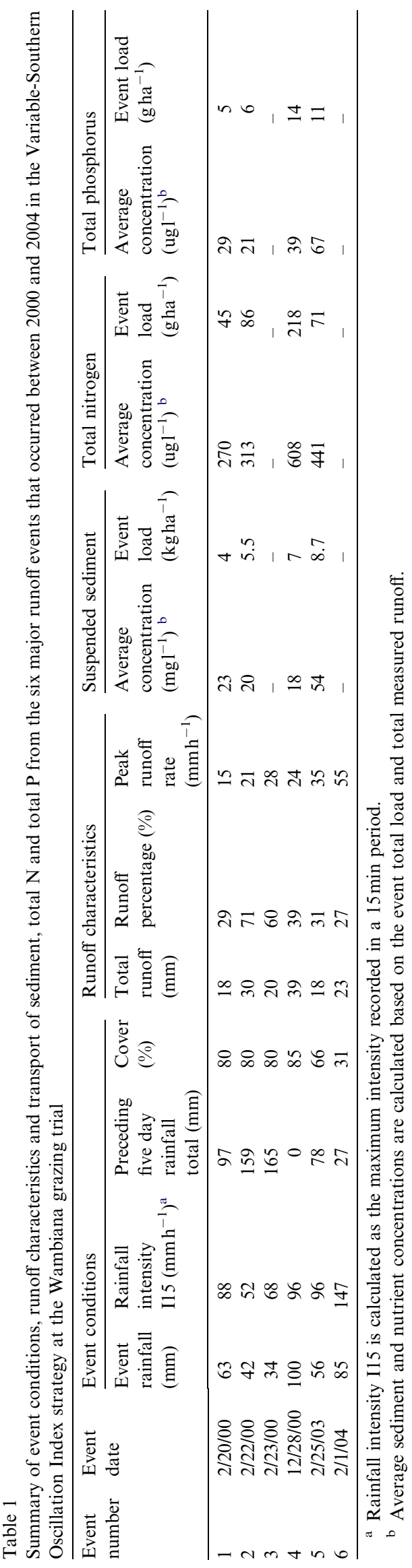


condition and species composition would be expected to significantly increase runoff and soil loss even in these catchments of relatively low slope.

Mean percentage runoff per event over all treatments was $26 \%$ but varied between $1 \%$ and $71 \%$ depending upon rainfall intensity, antecedent soil moisture and cover (Table 2). Runoff was, on certain occasions, generated by high volume, high intensity rainfall events falling on relatively dry soil (Fig. 3). This typically occurred at the start of the wet season such as the events of the 28 December 2000 (event 4) and 1 February 2004 (event 6). Runoff event 6 had the highest 15-min maximum rainfall intensity and the lowest cover relative to other events and accordingly the largest peak runoff rate. In this event runoff obviously occurred when the rainfall intensity exceeded the infiltration rate of the unsaturated surface soil, resulting in a sharp runoff peak of relatively short duration (Fig. 3).

The majority of runoff events however, occurred later in the wet season when rain fell on soils with high antecedent soil moisture (O'Reagain, pers. obs.). For example, runoff events 1, 2, 3 and 5 occurred after good falls of rainfall occurred over the preceding few days (Table 1). In event 2 , runoff occurred despite the relatively low rainfall intensity: here runoff apparently occurred due to the inability of water to enter the saturated profile leading to a prolonged runoff event with a relatively low peak (Fig. 3). Interestingly, events 2 and 3 had the greatest percentage runoff but required the smallest quantity of rainfall to generate surface runoff. In contrast, event 6 , which had the highest $15-\mathrm{min}$ maximum rainfall intensity of all events, lost only $27 \%$ of rainfall as runoff.

In all runoff events, water flow and the associated loss of sediment and nutrients from a site followed a typical pattern (Fig. 5): once rainfall of sufficient quantity to cause runoff occurred, overland flow was generated resulting in a rapid rise in flow height through the flume to peak flood volume. Flow height then declined as overland flow decreased through the event, giving a skewed, sharply bell-shaped curve. Nutrient and sediment levels in runoff water were highest early in the event as runoff rates were increasing but thereafter declined sharply as the event proceeded. This pattern arises from the flushing of accumulated soluble nutrients and sediment from disaggregated soil in the first flood flow and is in agreement with published trends for both large

Table 2

Mean, maximum and minimum values for $\%$ runoff and the total loss of sediment, bed load, $\mathrm{N}$ and $\mathrm{P}$ from runoff catchments per event over all grazing strategies at the Wambiana grazing trial

\begin{tabular}{lcclrl}
\hline & \% Runoff & $\begin{array}{l}\text { Sediment loss } \\
\left(\mathrm{kgha}^{-1}\right)\end{array}$ & $\begin{array}{l}\text { Bed load } \\
\left(\mathrm{kgha}^{-1}\right)\end{array}$ & $\begin{array}{l}\mathrm{N} \text { loss } \\
\left(\mathrm{gha}^{-1}\right)\end{array}$ & $\begin{array}{l}\text { P loss } \\
\left(\mathrm{g} \mathrm{ha}^{-1}\right)\end{array}$ \\
\hline Mean & 26 & 7 & 0.591 & 296 & 14 \\
Maximum & 71 & 20 & 2.837 & 1900 & 71 \\
Minimum & 1 & 3 & 0.019 & 10 & 1 \\
\hline
\end{tabular}
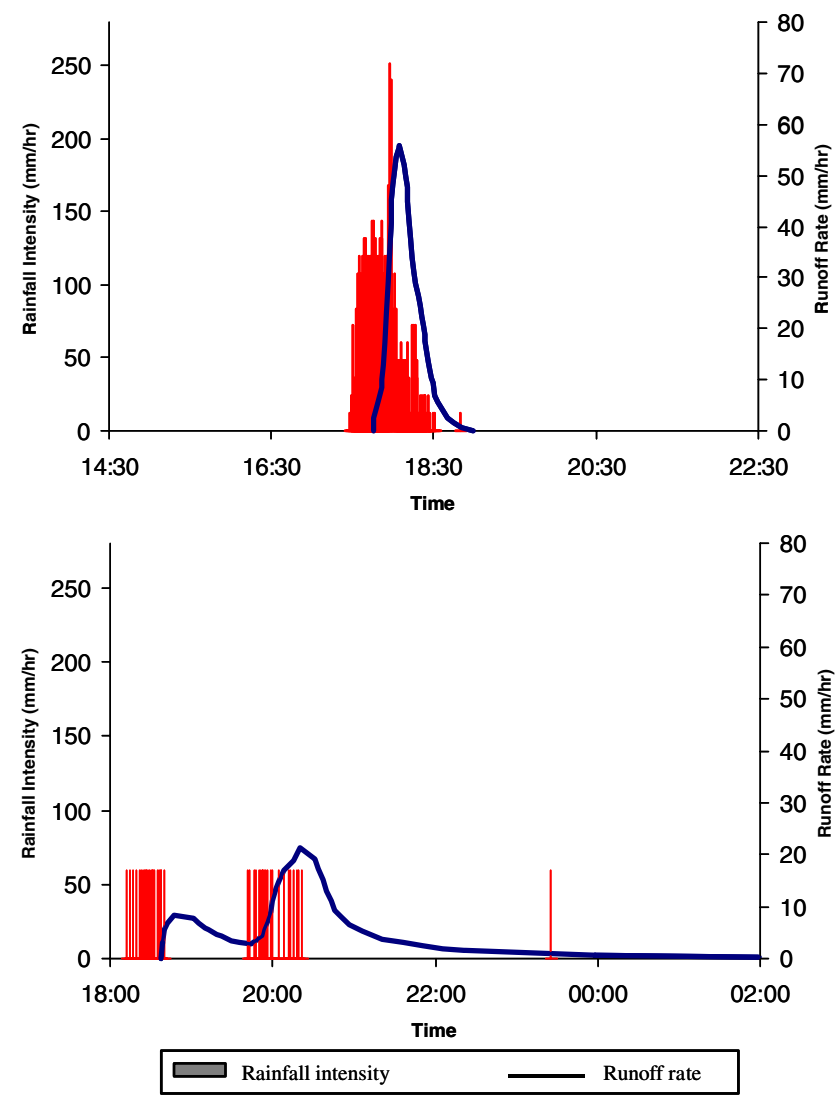

Fig. 3. Runoff rate and rainfall intensity for a high intensity (event 6 : top) and low intensity (event 2: bottom) runoff event at the Wambiana grazing trial.

(Mitchell et al., 1997) and plot-scale catchments (Faithful and Finlayson, this volume).

Runoff water quality was generally moderate across all treatments with relatively low concentrations of total $\mathrm{N}$ (range: $101-4000 \mu \mathrm{gl}^{-1}$ ), total P (range: $14-609 \mu \mathrm{g} 1^{-1}$ ) and total suspended sediment (range: $8-1409 \mathrm{mgl}^{-1}$ ) recorded (Fig. 4a,f,j). As the concentrations of sediments and nutrients were low, only very small quantities of total sediment and nutrient were moved off site (Table 1).

Although treatment differences appear to be present for certain water quality parameters, these should be viewed with caution given the small number of water samples collected for the 'light', 'variable' and 'rotational spell' treatments. In particular, the high levels of ammonia for the 'heavy' and 'light' strategies probably reflects that on occasion, animals in these treatments camped immediately up-slope of the flume, rather than any treatment differences per se.

The grazing trial results contrast markedly with the concentrations of nutrients and suspended sediment recorded in rivers and creeks across the Burdekin catchment (Fig. 4a-j). Trial water quality was similar to that of the Cape and Campaspe Rivers, which also drain the flatter, tertiary landscapes on which the trial is situ- 

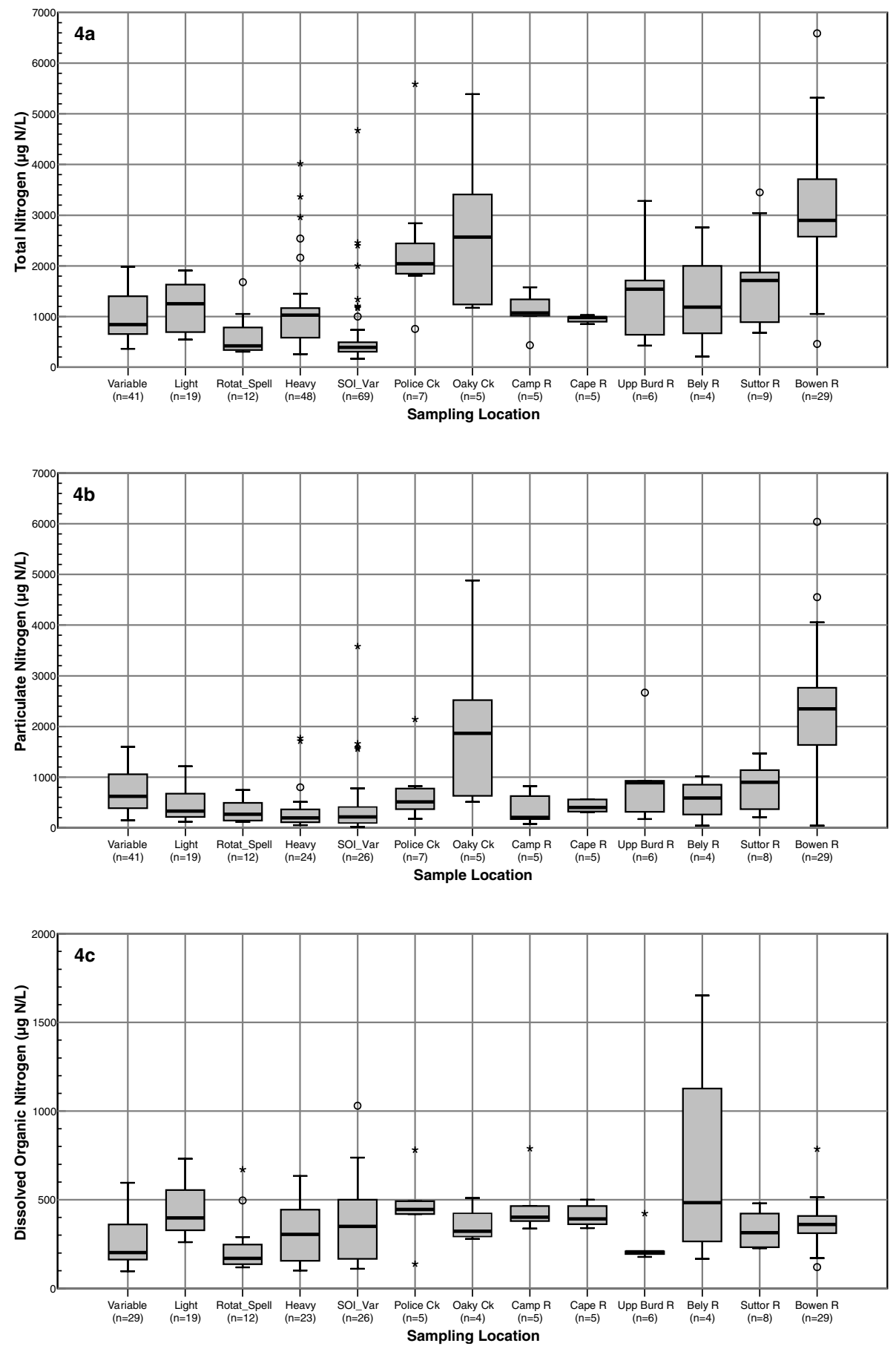

Fig. 4. Box plot showing the distribution of (a) total nitrogen, (b) particulate nitrogen, (c) filterable organic nitrogen, (d) $\mathrm{NO}_{X}$ (nitrate + nitrite), (e) ammonia (as $\mu \mathrm{g} \mathrm{N} / \mathrm{L}$ ), (f) total phosphorus, (g) particulate phosphorus, (h) filterable organic phosphorus, (i) filterable reactive phosphorus (as $\mu \mathrm{g}$ $\mathrm{P} / \mathrm{L}$ ) and (j) total suspended solids ( $\mathrm{mg} / \mathrm{L}$ ) concentrations in the runoff from the Wambiana mini-catchments, and in the event flows in rivers and creeks within the Burdekin River Catchment. Box plots for $\mathrm{NO}_{X}$ and total suspended solids are provided with two ranges: (i) $\mathrm{NO}_{X}$ range $0-4500 \mu \mathrm{g}$ $\mathrm{N} / \mathrm{L}$; TSS range $0-9000 \mathrm{mg} \mathrm{L}^{-1}$ and (ii) $\mathrm{NO}_{X}$ range $0-1000 \mu \mathrm{g} \mathrm{N} / \mathrm{L}$; TSS range $0-2000 \mathrm{mg} \mathrm{L}^{-1}$. Additional data for the Bowen River at Myuna sourced from Post (unpubl. data). The box length is the inter-quartile range (25th to 75 th inter-quartiles), with the median denoted by the dark line within the box. Outliers (circles) are values that are between 1.5 and 3 box lengths from the upper or lower edge of the box, and extreme cases (stars) are values more than 3 box lengths from the upper or lower edge of the box.

ated. This is significant as it indicates that the minicatchments provide an accurate estimate of the sediment and nutrients actually entering and moving through waterways in this area. Trial water quality was however significantly better than samples collected both from nearby Oaky Creek as well as those collected from more distant water courses like the Bowen and Burdekin rivers. The low levels of sediment and nutrient loss from 

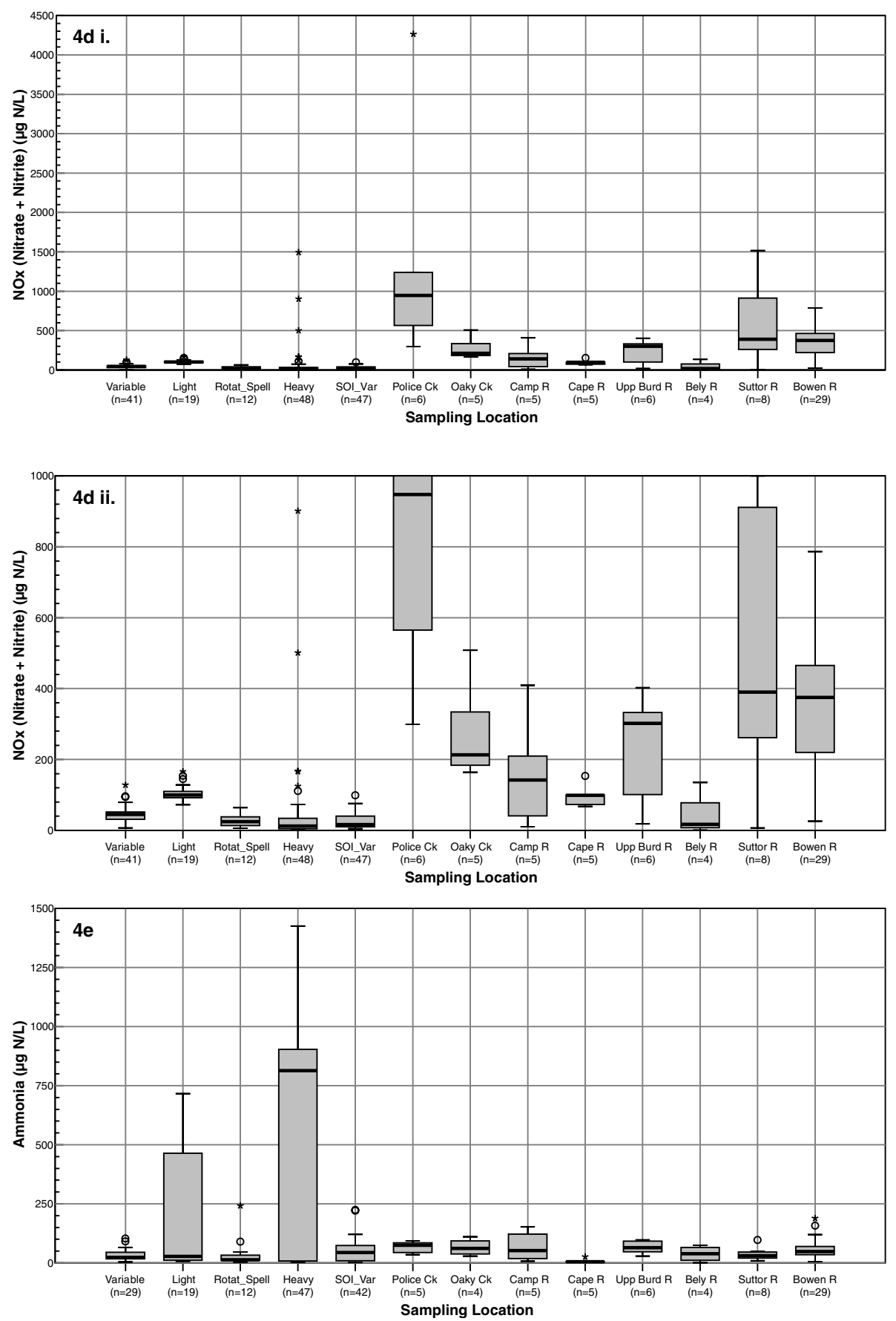

Fig. 4 (continued)

the grazing trial may be attributed to a number of factors including high ground cover levels and the low slope of the study area $(<1.8 \%)$. Oaky Creek in comparison drains undulating, grano-diorite landscapes which are typically overgrazed with low cover and have active hill slope and gully erosion (O'Reagain pers. obs.).

Relative to other studies, total sediment loss per unit area was surprisingly low (Table 1) with total soil loss (suspended sediment and bed load) varying from 3 to a maximum of $20 \mathrm{kgha}^{-1}$ per event. Although compara- ble data are not available, losses of $\mathrm{N}$ (range: 10 $1900 \mathrm{gha}^{-1}$ ) and P (range: $1-71 \mathrm{gha}^{-1}$ ) from the runoff catchments also appear low. In comparison, sediment movements of $40-590 \mathrm{kgha}^{-1}$ per annum have been recorded from small $\left(13 \mathrm{~km}^{2}\right)$ catchments dominated byBothriochloa pertusa on grano-diorite landscapes east of Charters Towers (Roth et al., 2003). Similarly, Scanlan et al. (1996) reported sediment movements of $10-1000 \mathrm{kgha}^{-1}$ per annum from small runoff plots $\left(250-1200 \mathrm{~m}^{2}\right)$ on grano-diorite landscapes near Char- 

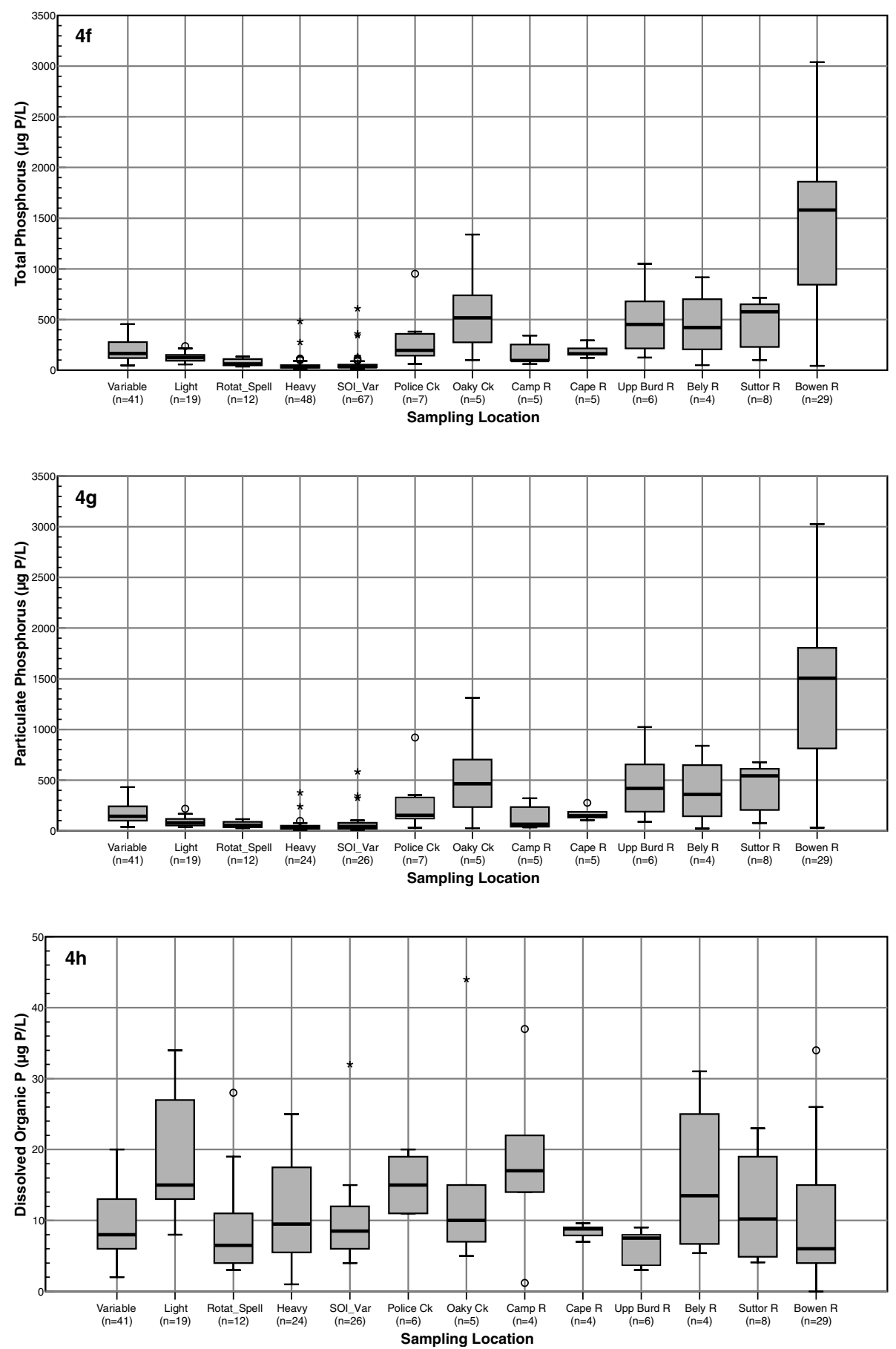

Fig. 4 (continued)

ters Towers and undulating, sedimentary landscapes near Greenvale. Comparisons between different data sets should, of course, be conducted with caution, given differences in methodology, scale, land type, rainfall and cover between different studies. Nevertheless, the measured rates of soil loss at the Wambiana site suggest that these relatively flat tertiary sediments (Rogers et al., 1999) contribute substantially less per unit area to overall sediment loads than steeper, more erodable, grano- diorite and sedimentary landscapes in other parts of the Burdekin.

\subsection{Water quality in rivers and creeks across the Burdekin catchment}

The sub-catchments of the Burdekin system described in this study have varying catchment characteristics. Brief summaries of these are listed below. 

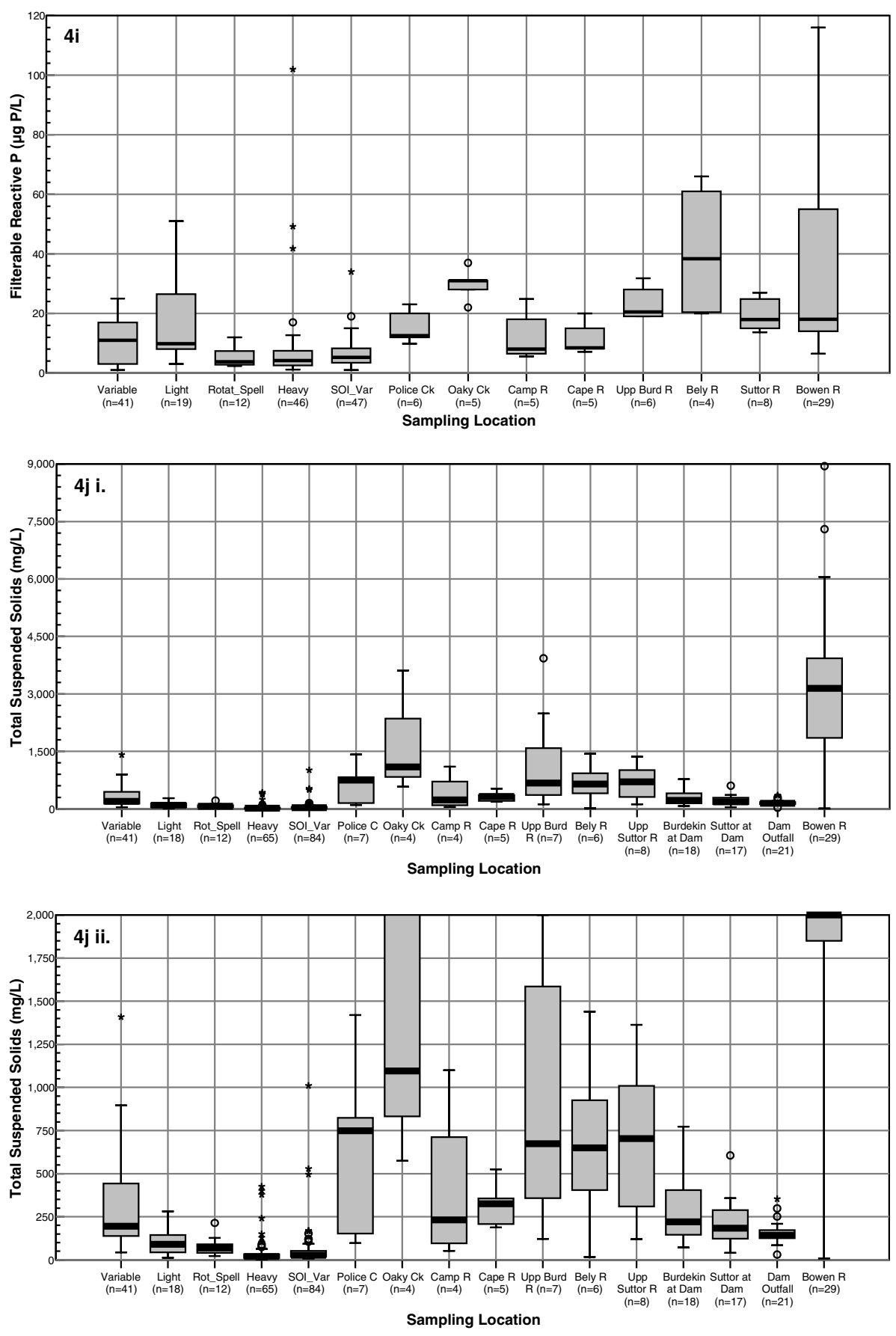

Fig. 4 (continued)

- Upper Burdekin River: a large catchment with many land types, varied relief and moderate to heavy stocking. Some sodic areas with deep gullies occur as well as some very erodible hill slopes near Greenvale on undulating, sedimentary country. Hilly, erodible landscapes also occur around Charters Towers.

- Bowen River: a moderate to large sized catchment, hilly in places with grano-diorite, basalt and sedimentary soils, sodic soils on river bank lead to localised severe gullying. Many areas are overgrazed with low cover.
- Belyando River: moderate sized catchment, very slow flowing, big areas of clay soils/cleared Gidyea with Buffel grass, relatively flat country but some steep hills in places. Some dry land cropping occurs near Clermont. Cover low to moderate. Chronic turbidity due to the nature of soils in catchment which cause the river to be grey in colour during flow conditions.

- Suttor River: a smaller catchment with a very different geology to the Belyando. The river arises in the steep, rocky Leichardt range and then drains large 

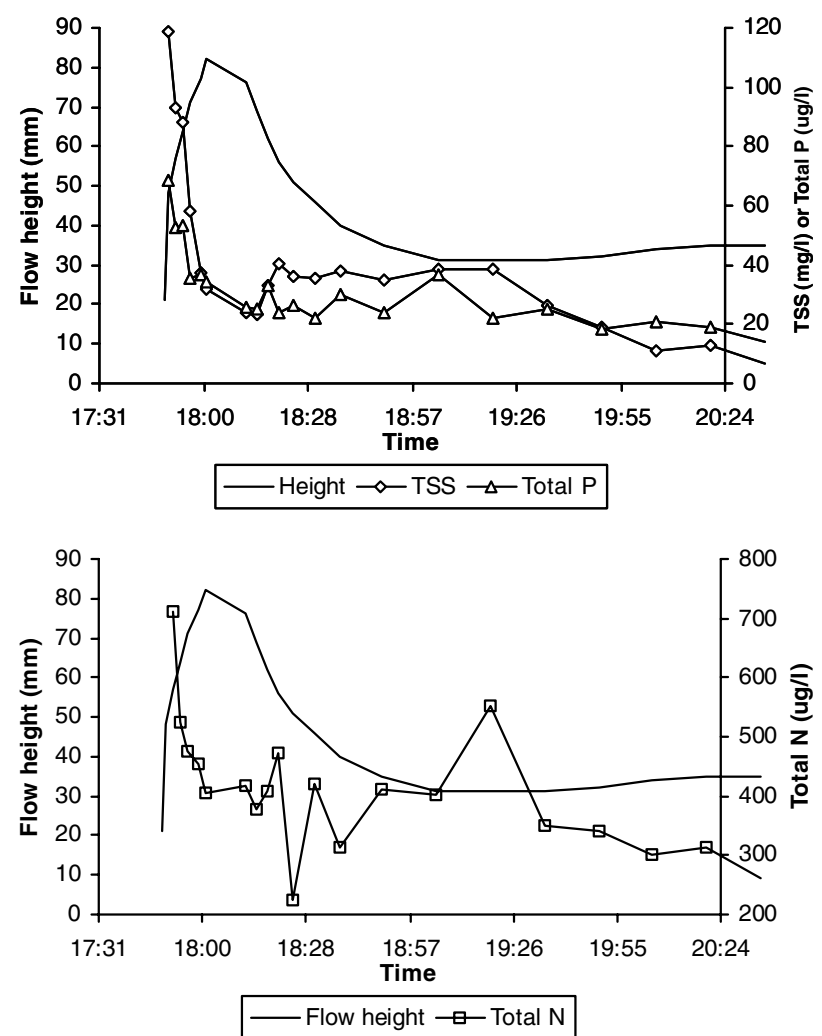

Fig. 5. Change in total suspended sediment (TSS) and total P (top) and total $\mathrm{N}$ in runoff water (bottom) with flow height during a runoff event in the 'Variable' grazing treatment on the Wambiana grazing trial on 19 February 2000.

cleared areas of sedimentary clay country, as well as grano-diorite soils near the Burdekin Falls Dam. Variable stock numbers with some areas very bare. The river has a red colour when in full flow conditions.

- Cape and Campaspe Rivers: moderate catchment size, generally flatter, less erodible country although headwaters of both arise in very steep granite/sedimentary landscapes. This steep country does not seem to erode extensively due to the shallow, stony nature of the soils. Cover moderate to good, with lower cattle numbers than Oaky Creek or the Bowen River.

- Policeman Creek: a small catchment with headwaters in hilly areas but generally drains the same tertiary sediments as the Cape and Campaspe Rivers. Cover fair to moderate. The Highway Reward Mine has carried out extensive revegetation works of waste dumps close to drainage lines. Some evidence of contamination with ore along roads shedding water into the creek.

- Oaky Creek: a small catchment draining undulating grano-diorite soils with very low cover and extensive gullying in places.

In contrast to the grazing trial, water samples collected from rivers and creeks displayed significantly higher levels of total $\mathrm{N}$ (range: $650-6350 \mu \mathrm{g} \mathrm{N}^{-1}$ ), total $\mathrm{P}$ (range: $50-1500 \mu \mathrm{gP}^{-1}$ ) and total suspended sediment (range: $10-6010 \mathrm{mgl}^{-1}$ ) (Fig. 4a,f,j). In particular, samples from creeks draining the hillier, grano-diorite landscapes contained consistently higher loads of sediment relative to those draining flatter landscapes of tertiary sedimentary origin. These discrepancies can be largely attributed to the marked differences in slope, geology and cover between the catchments of some of the watercourses sampled and those of the mini-catchments.

Differences between major sub-catchments of the Burdekin can be seen for some parameters measured in event flows (Fig. 4a-j) although the data needs to be used with care given they represent single events in a single year. Total suspended sediment (TSS), particulate nitrogen (PN) and particulate phosphorus (PP) were highest in the Bowen River, moderate and similar to each other in the Belyando, Suttor and upper Burdekin Rivers and lowest in the Cape River. The Bowen catchment with its severe gully erosion, steep slopes on the eastern side and history of overgrazing in certain parts, is a major source of TSS and particulate nutrients to the Burdekin system. This has been predicted from modelling studies (Prosser et al., 2002; Brodie et al., 2003; McKergow et al., (a) this volume, (b) this volume) and catchment assessment studies (Roth et al., 2002). The event data from the Bowen partly validates these predictions with event median TSS, PN and PP concentrations of $3100 \mathrm{mgl}^{-1}, 2400 \mu \mathrm{g} \mathrm{N1}^{-1}$ and $1500 \mu \mathrm{gl}^{-1}$ respectively. In contrast, the Cape catchment with its flatter topography and better pasture cover has an order of magnitude lower TSS, PN and PP concentrations (350 $\mathrm{mg}^{-1}, 400 \mu \mathrm{g} \mathrm{N}^{-1}$ and $150 \mu \mathrm{gPl}^{-1}$ respectively).

Differences between the dissolved organic nitrogen (DON) and dissolved organic phosphorus (DOP) (also called filterable organic $\mathrm{N}$ and $\mathrm{P}$ ) concentrations at both the grazing trial and wider catchment sites are small (Fig. 4c,i) with the range of all medians being 200$500 \mu \mathrm{g} 1^{-1}$ for DON and $6-17 \mu \mathrm{g} 1^{-1}$ for DOP. These levels are not unexpected as dissolved organic nutrients are considered the 'natural' form of nutrient leakage from natural landscapes covered by both forest, savannah or grasslands (van Breemen, 2002) and are not strongly increased by land use change. Land use change from undisturbed natural vegetation to low intensity uses such as rangeland grazing leads to an overall increase in the export flux of nitrogen and phosphorus and an increase in the proportion of PN and PP (through soil erosion) in the total nitrogen (TN) and phosphorus (TP) flux (Harris, 2001). Although soil nitrogen levels are low in the arid and semi-arid areas of Australia such as the Burdekin (Williams and Raupach, 1983), much of the nitrogen is located in the upper few centimetres of the soil profile (Attiwill and Adams, 1993) and so erosion of this layer can lead to substantial PN and DON losses (Schmidt and Lamble, 2002). Thus in runoff from 
natural savannah we would expect to see the TN and TP export dominated by DON and DOP. In contrast under extensive grazing in savannas, we expect to see an increase in TN and TP export and also in the proportion of PN and PP in the total. This is supported from the results of this study although we only have sites along a gradient from natural savannah to savannah with relatively heavy grazing and no sites with no grazing in the sub-catchment.

In fertilised cropping lands, the major change is to a dominance of dissolved inorganic nitrogen (DIN) loss, often nitrate, and to a lesser extent dissolved inorganic phosphorus (DIP), often FRP, in the $\mathrm{N}$ and $\mathrm{P}$ export pool (Harris, 2001). This effect is not evident in the present data as cropping is a very minor component of land use in the catchment and DIN and DIP concentrations are generally low (medians of $<400 \mu \mathrm{g} \mathrm{N} 1^{-1}$ for nitrate and $<40 \mu \mathrm{gP}^{-1}$ for FRP (equivalent to DIP)). The exception is Policeman Creek where the median nitrate level was $950 \mu \mathrm{g} \mathrm{N}^{-1}$ but this anomaly may be associated with runoff from rehabilitated waste piles at the Highway Reward base metals mine, located a few kilometres up-stream from the sampling site.

Depth-averaged TSS concentrations in the Burdekin Dam (Lake Dalrymple) were lower than the range of concentrations determined in the upstream rivers (Fig. 4j). This may be considered primarily a result of the de-powering of storm inflows as they enter the reservoir and the resultant sedimentation of the suspended particulate matter that occurs with that reduction in flow rates. The bulk of the turbidity associated with the Burdekin Dam is attributed to fine clays (Amos et al., 2004; Faithful and Griffiths, 2000) that persist in the water column, as the coarser grained suspended particulate matter, which provides the bulk of the TSS mass, is deposited to the benthic sediment layers in the early stages of the riverine zone of the lake. The increase in TSS concentrations downstream that have been noted for wet season event flows downstream of the dam (e.g. at Home Hill, Mitchell and Furnas, 1996) reflects the lower catchment inputs to the Lower Burdekin River (e.g. Bowen River) in addition to the fine TSS that is carried over the dam wall.

\section{Conclusions}

The present data suggest that at least on the relatively flat sedimentary landscapes of the Burdekin catchment, extensive cattle grazing is compatible with achieving an acceptable standard of water quality, provided adequate levels of ground cover are maintained. In contrast, data from creeks and rivers in the catchment suggest nutrient and sediment loss is a serious issue on certain land types, particularly those of grano-diorite origins. Aside from their obvious consequences for water quality, these losses are also likely to have serious implications for the long-term productivity and sustainability of grazing operations in these areas. A further important conclusion from the sediment and nutrient loss data from the grazing trial is that in a highly variable climatic regime like the Burdekin, long periods are required in order to detect any response in water quality to management change. Australian rivers in general (Finlayson and McMahon, 1988), and Australian dry tropics rivers in particular, have highly variable rainfall and flow regimes which strongly influence their eco-hydrology (Puckridge et al., 1998). Under these conditions, detection of shortterm trends in water quality is extremely difficult and periods in excess of 20 years may be required before any response to management actions e.g. reduced stocking rates, can be detected. The grazing trial results show this clearly and we may only expect to see conclusive differences in sediment and nutrient losses from the treatments after several more years of the trial.

Despite identical land use i.e. extensive cattle grazing, large differences in the concentrations of TSS and nutrients in flow events were apparent between the major sub-catchments of the Burdekin. This clearly shows that in such circumstances, a range of natural factors as well as land use and land management practices determine water quality. These natural factors include climate, topography, geomorphology, geology, soil type and vegetation community type. These results reinforce the conclusions noted above that detecting catchment scale trends in water quality due to land use management initiatives will be extremely difficult against the highly variable background of natural factors. Catchment scale monitoring of water quality accordingly has to be conducted over the long term.

\section{Acknowledgment}

We are grateful to the Lyons family of 'Wambiana' for their continued support in running the grazing trial and we thank the various graziers who collected water samples during flood events. Field data at 'Wambiana' was collected by Richard Allen and Peter Allen. Katrina Cullen coordinated the Burdekin catchment sampling with valuable support from numerous landholders in the catchment. Water sample analyses were conducted by Jenny Cook, Sarah Thornton, Vivien McConnell and Joanne Knott (ACTFR). Funding support for the grazing trail was provided by Meat and Livestock Australia, the Great Barrier Reef Marine Park Authority and the CRC for Tropical Savanna Management. Support for the collection of water samples was provided by Burdekin Rangelands to Reef Initiative of Queensland Department of Primary Industries \& Fisheries and the National Action Plan for Water Quality and 
Salinity through the Burdekin Dry Tropics NRM Board.

\section{References}

Amos, K.J., Alexander, J., Horn, A., Pocock, G.D., Fielding, C.R., 2004. Supply limited sediment transport in a high-discharge event of the tropical Burdekin River, north Queensland, Australia. Sedimentology 51, 145-162.

APHA, 1998. Standard Methods for the Examination of Water and Wastewaters, 20th ed. American Public Health Association, American Water Works Association and Water Environment Federation, Washington, USA.

Attiwill, P.M., Adams, M.A., 1993. Nutrient cycling in forests. New Phytology 124, 561-582.

Brodie, J.E., 2002. Keeping the wolf from the door: managing landbased threats to the Great Barrier Reef. In: Moosa, M.K., Soemodihardjo, S., Soegiarto, A., Romimohtarto, K., Nontji, A., Soekarno, S. (Eds.), Proceedings of the Ninth International Coral Reef Symposium, October, 2000, Bali, Indonesia, vol. 2, pp. 705714.

Brodie, J., Faithful, J., Cullen, K., 2004. Community water quality monitoring in the Burdekin River catchment and estuary-20022004. Australian Centre for Tropical Freshwater Research Report No. 03/16, James Cook University, Townsville.

Brodie, J., McKergow, L.A., Prosser, I.P., Furnas, M., Hughes, A.O., Hunter, H., 2003. Sources of sediment and nutrient exports to the Great Barrier Reef World Heritage Area. Australian Centre for Tropical Freshwater Research Report No. 03/11, James Cook University, Townsville.

De Corte, M., Cannon, M., Barry, E., Bright, J., Scanlan, J., 1991. Land degradation in the Dalrymple Shire: a preliminary assessment. CSIRO, Davies Laboratory, Townsville.

Devlin, M., Waterhouse, J., Taylor, J., Brodie, J., 2001. Flood plumes in the Great Barrier Reef: spatial and temporal patterns in composition and distribution. GBRMPA Research Publication No. 68, Great Barrier Reef Marine Park Authority, Townsville, Australia.

Devlin, M., Brodie, J., Waterhouse, J., Mitchell, A., Audas, D., Haynes, D., 2003. Exposure of Great Barrier Reef inner-shelf reefs to river-borne contaminants. In: Dawson N, Brodie J, Rayment, G., (Eds.), Proceedings of the Second National Conference on Aquatic Environments: Sustaining Our Aquatic EnvironmentsImplementing solutions. Queensland Department of Natural Resources and Mines, Brisbane, Australia.

Fabricius, K.E., De'ath, G., 2004. A framework to identify ecological change and its causes: a case study of terrestrial run-off on coral reefs. Ecological Applications 14, 1448-1465.

Faithful, J.W., Finlayson, W., this volume. Water quality assessment for sustainable agriculture in the Wet Tropics-a communityassisted approach. In: Hutchings, P.A., Haynes, D. (Eds.), Proceedings of Catchment to Reef: Water Quality Issues in the Great Barrier Reef Region Conference. Marine Pollution Bulletin.

Faithful, J.W., Griffiths, D.J., 2000. Turbid flow through a tropical reservoir (Lake Dalrymple, Queensland, Australia): responses to a summer storm event. Lakes and Reservoirs: Research and Management 5, 231-247.

Finlayson, B.L., McMahon, T.A., 1988. Australia $v$ the World: A comparative analysis of streamflow characteristics. In: Warner, R.F. (Ed.), Fluvial Geomorphology of Australia. Academic Press, Sydney.

Furnas, M., 2003. Catchments and Corals: Terrestrial Runoff to the Great Barrier Reef. Australian Institute of Marine Science and CRC Reef Research Centre, Townsville, 334 pp.
Griffiths, D.J., Faithful, J.W., 1996. Effects of the sediment load of a tropical north Australian river on water column characteristics in the receiving impoundment. Archive de Hydrobiologie Supplement. 113 Large Rivers 10(1-4), 147-157.

Harris, G.P., 2001. Biogeochemistry of nitrogen and phosphorus in Australian catchments, river and estuaries: effects of land use and flow regulation and comparisons with global patterns. Marine and Freshwater Research 52, 139-149.

Hosomi, M., Sudo, R., 1987. Simultaneous determination of total nitrogen and total phosphorus in freshwater samples using persulfate digestion. International Journal Environmental Studies 27, 267-275.

Isbell, R.F., 1996. The Australian Soil Classification. CSIRO Publishing, Melbourne.

King, B., McAllister, F., Wolanski, E., Done, T., Spagnol, S., 2001. River plume dynamics in the central great barrier reef. In: Wolanski, E. (Ed.), Oceanographic Processes of Coral Reefs: Physical and Biological Links in the Great Barrier Reef. CRC Press, Boca Raton, pp. 145-160.

McCulloch, M., Fallon, S., Wyndham, T., Hendy, E., Lough, J., Barnes, D., 2003. Coral record of increased sediment flux to the inner Great Barrier Reef since European settlement. Nature 421, 727-730.

McIvor, J.G., Williams, J., Gardner, C.J., 1995. Pasture management influences runoff and soil movement in the semi-arid tropics. Australian Journal of Experimental Agriculture 35, 55-65.

McKergow, L.A., Prosser, I P., Hughes, A.O., Brodie, J., this volume. Sources of sediment to the Great Barrier Reef World Heritage Area. In: Hutchings, P.A., Haynes, D. (Eds.), Proceedings of Catchment to Reef: Water Quality Issues in the Great Barrier Reef Region Conference. Marine Pollution Bulletin.

McKergow, L.A., Prosser, I.P., Hughes, A.O., Brodie, J., this volume. Regional scale nutrient modelling: exports to the Great Barrier Reef World Heritage Area. In: Hutchings, P.A., Haynes, D. (Eds.), Proceedings of Catchment to Reef: Water Quality Issues in the Great Barrier Reef Region Conference. Marine Pollution Bulletin.

Mitchell, A.W., Bramley, R.G.V., Johnson, A.K.L., 1997. Export of nutrients and suspended sediment during a cyclone-mediated flood event in the Herbert River catchment, Australia. Marine and Freshwater Research 48, 79-88.

Mitchell, A.W., Furnas, M.J., 1996. Terrestrial inputs of nutrients and suspended sediments to the GBR lagoon. In: The Great Barrier Reef; Science, Use and Management-A National Conference, Proceedings, James Cook University, Townsville, CRC Reef Research Centre, James Cook University, vol. 1, pp. 59-71.

O'Reagain, P., Bushell, J., 1999. Testing grazing strategies for the seasonally variable tropical savannas. In: Eldridge, D., Freudenberger, D. (Eds.), Proceedings Sixth International Rangelands Congress, Townsville, Australia, July 1999, pp. 485-486.

Prosser, I.P., Moran, C.J., Lu, H., Scott, A., Rustomji, P., Stevenson, J., Priestly, G., Roth, C.H., Post, D., 2002. Regional patterns of erosion and sediment transport in the Burdekin River catchment. CSIRO Land and Water Technical Report 5/02, CSIRO, Canberra.

Puckridge, J.T., Sheldon, F., Walker, K.F., Boulton, A.J., 1998. Flow variability and the ecology of large rivers. Marine and Freshwater Research 49, 55-72.

Rogers, L.G., Cannon, M.G., Barry, E.V., 1999. Land resources of the Dalrymple shire. Queensland Department of Natural Resources, Brisbane. 237 pp.

Roth, C.H., Lawson, G., Cavanagh, D., 2002. Overview of key natural resource management issues in the Burdekin Catchment, with particular reference to water quality and salinity. Burdekin Catchment Condition Study Phase 1. Burdekin Dry Tropics Board, Townsville.

Roth, C.H., Prosser, I.P., Post, D.A., Gross, J.E., Webb, M.J., 2003. Reducing sediment export from the Burdekin catchment. CSIRO Land \& Water, NAP3.224. 
Scanlan, J.C., Pressland, A.J., Myles, D.J., 1996. Run-off and soil movement on mid-slopes in north-east Queensland and grazed woodlands. Rangelands Journal 18, 33-46.

Schmidt, S., Lamble, R.E., 2002. Nutrient dynamics in Queensland savannas: Implications for the sustainability of land clearing for pasture production. Rangelands Journal 24, 96-111.

Tothill, J.C., Hargreaves, J.N.G., Jones, R.M., McDonald, C.K., 1992. BOTANEL - a comprehensive sampling and computing procedure for estimating pasture yield and composition 1. Field sampling. CSIRO Tropical Agronomy Memo. \#78. van Breemen, N., 2002. Natural organic tendency. Nature 415, 381382.

Williams, C.H., Raupach, M., 1983. Plant nutrients in Australian soils. In: Soils: an Australian Viewpoint. CSIRO, Melbourne and Academic Press, London, UK, pp. 777-793.

Wolanski, E., van Senden, D., 1983. Mixing of Burdekin river floodwaters in the great barrier reef. Australian Journal of Marine and Freshwater Research 34, 49-63. 